\title{
LAKE TOURISM DEVELOPMENT IN UTENA COUNTY
}

\section{Daubarienė Jurgita}

Utena University of Applied Sciences, Utena, Lithuania

\section{ANNOTATION}

The biodiversity of lakes makes them important as natural resource for tourism. Lakes all over the world are used as a resource for ecotourism, natural tourism, leisure tourism and they attract millions of tourists. The use of lakes for sports, entertainment, swimming, fishing, etc. is of great importance to the public.

There are 2835 lakes larger than 0.5 ha in Lithuania. Utena County has 35\% share of all Lithuanian lakes larger than 0.5 ha. So this is a very important region of lake tourism development in Lithuania. The objective of the article was to analyse lake tourism development in Utena County. The article reviews the significance of lake tourism development, analyses the lake resources of the Utena County. The article assesses morphometric parameters and lakeshore features of Utena County lakes important for tourism development and examines lake tourism opportunities in Utena County. Scientific literature, web sites, legislation on lake tourism and recreational activities on the lakes and in the lakeshore, ArcGis software programme were used as references for writing the article.

Keywords: lake tourism, lakes' morphometric parameters, lakes' accessibility by roads, landscape structure of lakes.

\section{INTRODUCTION}

The biodiversity of lakes makes them important as natural resource for tourism. Lakes all over the world are used as a resource for ecotourism, natural tourism, leisure tourism and they attract millions of tourists. The use of lakes for sports, entertainment, swimming, fishing, etc. is of great importance to the public.

Lakes tourism is tourism with the purpose to rest at the lakes. Lake tourism occurs not only on the lake itself, but also the lake surrounding area (Goeldner et al., 2000).

Lake tourism includes rural activity, boating, fishing, swimming, sun bath and other activities (Ryhanen, 2001). Lacustrine tourism systems therefore include the lake, the foreshore and those amenities, facilities and infrastructure in the surrounding that support the role of the lake as a tourist attraction. The environmental system that underlies the lake tourism system is usually much larger in area and includes lake, lakeshore and lake surrounding region (Lerner, Haber, 2000).

There are many lake-based destinations around the world for which visitation runs into the millions - for example, the lake districts of England, Finland as well as the lake systems of Hungary, Scotland, Switzerland, northern Italy, New Zealand, western Canada and the United States as well as, of course, the Great Lakes of North America, which are arguably the most researched lake systems in the world in terms of tourism and recreation. (Hall, Härkönen, 2006).

The 12th World Lake Conference TAAL 2007 held in Jaipurin November 2007 recognized the importance of lakes for domestic and recreational uses and ecotourism (Ranade, 2008). 
There are 2835 lakes larger than 0.5 ha in Lithuania. Utena County has $35 \%$ share of all Lithuanian lakes larger than 0.5 ha. So this is a very important region of lake tourism development in Lithuania.

The object of the research are bigger than 0.5 ha lakes of Utena County, and the aim was to analyse lake tourism development possibilities in Utena County.

\section{RESEARCH METHODS}

Scientific literature, web sites, legislation on lake tourism and recreational activities on the lakes and in the lakeshore, ArcGis software programme were used as references for writing the article.

There are 1001 lakes, bigger than 0.5 ha, in Utena County. Since there are a great number of lakes, in order to distinguish their patterns, lakes were grouped into 7 area classes: $0.5-1$ ha; $1.1-$ 5 ha; 5.1-10 ha; 10.1-50 ha; 50.1-100 ha; 100.1-500 ha; > 500 ha. Articles distinguish the most important criteria of lakes tourism development: lakes morphometric parameters, lakes accessibility of roads, landscape structure of lakes. The marphometric parameters, used in the present paper, were taken from the Catalogue of Lithuanian SSR (1964), while bathymetric parameters were taken from list with bathymetric data (1964). To determine the accessibility of lakes, ArcGis10 software was used. It was worked with GDB10LT database (updated in January, 2008). The data of lakes was taken from layer "Areas". This layer of lakes was re-covered with layers of "Roads" and "Railways". Seeking to assess the accessibility of lakes by roads of various types, search for roads was implemented at the radius of 10, 50, 100, 200 and 500 metres around lakes. The paper sought to determine the landscape structure of Utena County lakes. Lake shore landscapes are natural (N) forests, swamps, grasslands etc. (gardens, water bodies) and anthropogenical (A) - populated localities (there are six groups according to the number of population: $G_{I}-<20$ inhabitants, $G_{I I}-$ 20-99 inhabitants, $\mathrm{G}_{\mathrm{III}}-100-499$ inhabitants, $\mathrm{G}_{\mathrm{IV}}-500-999$ inhabitants, $\mathrm{G}_{\mathrm{V}}->1,000$ inhabitants, $\mathrm{G}_{\mathrm{VI}}$ - towns, centres of districts, capital), and roads (there are five types of roads: $\mathrm{K}_{\mathrm{I}}-$ motorway, highway, $\mathrm{K}_{\mathrm{II}}-$ asphalted road, $\mathrm{K}_{\mathrm{III}}-$ gravelled road, $\mathrm{K}_{\mathrm{IV}}-$ unsurfaced road, $\mathrm{K}_{\mathrm{V}}$ - railway). The distribution of forests, swamps, grasslands, residential areas and other landscapes in lake shores was analysed. These landscapes were analysed in buffers, drawn at the radius of $500 \mathrm{~m}$ around lakes. Forests, swamps, residential areas and other landscapes were taken from GDB10LT layer "Locations". After drawing the buffers of $500 \mathrm{~m}$ radius around lakes, the area of forests, swamps, residential areas and other landscapes was calculated.

\section{RESEARCH RESULTS AND DISCUSSION}

There are 2835 lakes larger than 0.5 ha in Lithuania. Utena County has 35\% share of all Lithuanian lakes larger than 0.5 ha. There are 1001 lakes. The research data shows that the most common lakes in Utena County are small lakes, less than 50 hectares (881 lakes) (Figure 1). There are 29 lakes larger than 500 ha in Lithuania. Utena County has $69 \%$ share of all Lithuanian lakes larger than 500 ha. It is very important for the development of recreational activities because the bigger the lake, the greater the opportunity to deploy it. 
There is no research or statistics on water tourist flows in Utena County. Due to abundance of lakes Utena County receives many holiday makers during the warm season and according to this indicator it falls behind the seaside area only (western part of Lithuania). Nevertheless, it is known that most popular types of boats are sculls, kayaks (70\%) and canoes (20\%) (Rytu Lietuvos.., 2003).

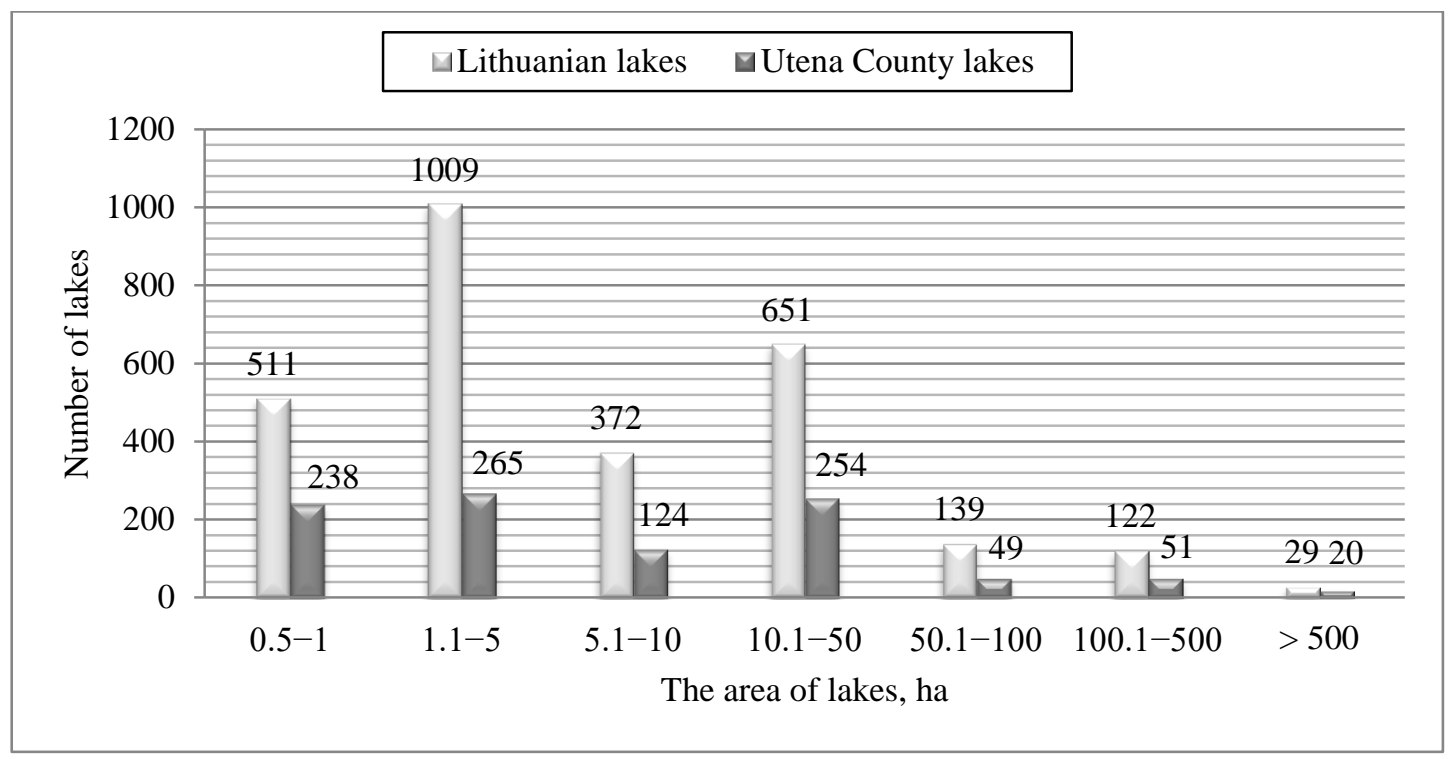

Figure 1. Distribution of different area lakes in Lithuania and in Utena County

The largest lakes of the county are: Druksiai $\left(44.8 \mathrm{~km}^{2}\right)$ and Dysnai $\left(24.2 \mathrm{~km}^{2}\right)$, the longest lakes - Asveja $(21.9 \mathrm{~km})$, Aisetas $(16 \mathrm{~km})$, Sartai $(14.4 \mathrm{~km})$, the deepest lakes - Tauragnas (60.5 m), Asveja (50.2 m), Baltieji Lakajai (45 m). The largest number of islands is in the Avilys Lake (Zarasai district). The lake is of 1258 ha and it has 31 islands. Baluoso Lake is quite unique which is in Ignalina district. It has several islands and one of the islands has its own internal deep lake. Lake Zarasas is quite attractive for recreation and is located right beside Zarasai city.

Table 1. Possibilities to use sailing means in the lakes according to the area of a lake in the territories that are not protected

\begin{tabular}{|c|c|c|c|}
\hline \multirow{2}{*}{$\begin{array}{c}\text { Interval of } \\
\text { lake's area, ha }\end{array}$} & \multicolumn{2}{|c|}{$\begin{array}{l}\text { Number of } \\
\text { lakes }\end{array}$} & \multirow[t]{2}{*}{ Sailing means } \\
\hline & $\mathrm{n}$ & $\%$ & \\
\hline $0.5-10$ & 627 & 63 & $\mathrm{~N}$ \\
\hline $10.1-100$ & 303 & 30 & $\begin{array}{l}\mathrm{N} \\
\mathrm{S}<10 \mathrm{AG}(8 \mathrm{~kW})^{*}\end{array}$ \\
\hline $100.1-200$ & 27 & 3 & $\begin{array}{l}\mathrm{N} \\
\mathrm{S}<10 \mathrm{AG}(8 \mathrm{~kW}) \\
\mathrm{S} 10 \mathrm{AG}(8 \mathrm{~kW})-20 \mathrm{AG}(15 \mathrm{~kW}) *\end{array}$ \\
\hline $200.1-500$ & 24 & 2 & $\begin{array}{l}\mathrm{N} \\
\mathrm{S}<10 \mathrm{AG}(8 \mathrm{~kW}) \\
\mathrm{S} 10 \mathrm{AG}(8 \mathrm{~kW})-150 \mathrm{AG}(110 \mathrm{~kW})^{*} \\
\text { Aircraft with floats or amphibian } \\
\end{array}$ \\
\hline$>500$ & 20 & 2 & $\begin{array}{l}\text { N } \\
\text { S < } 20 \text { AG }(15 \mathrm{~kW}) \\
\text { S } 21 \text { AG }(16 \mathrm{~kW})-300 \mathrm{AG}(220 \mathrm{~kW})^{*} \\
\text { Aircraft with floats or amphibian }\end{array}$ \\
\hline Total : & 1001 & 100 & \\
\hline
\end{tabular}

Note. $\mathrm{N}$ - non self-propelled means of sailing; $\mathrm{S}$ - self-propelled means of sailing;

$*$-from June 21 until the end of the navigation. 
One of the most popular recreational activities is sailing in lakes on the various sailing means. The area of lakes influences sailing by sailing means. The bigger the lake, the more powerful and various sailing means can be used. Laws (Dél aplinkosaugos.., 2004) put lakes into the following groups according to the area: until $10 \mathrm{ha}, 10.1-100,100.1-200,200.1-500$ and bigger than 500 ha lakes. It is prohibited to sail by self-propelled sailing means in smaller than 10 ha lakes; if a lake is $10-200$ ha, it is allowed to sail by the self-propelled sailing means whose total engine power does not exceed $15 \mathrm{~kW}$; in the lakes that are bigger than 200 ha it is allowed to sail by more powerful, up to $110 \mathrm{~kW}$ sailing means. If a lake size is bigger than 500 ha the selfpropelled sailing means whose total engine power does not exceed $220 \mathrm{~kW}$ can be used.

Utena County has 374 lakes (37\%) where you can use self-propelled boating means (area more than 10 hectares) and 60 lakes (6\%) (larger than 200 hectares) where you can use more highpowered boats. The water motorcycles can be used just in the Alausas Lake. Therefore Alausas is the most popular lake among users of sailing.

No lake of Utena district can be noted as exceptional in abundance of fish. Nevertheless, recreational fishing is still one of the regions' water-based tourism potential and still remains the niche in the market. According Virbickas and Domarkas (2006) recreational fisheries are most appropriate to mesotrophic, eutrophic and in part of hypertrophic lakes because they have natural maximum productivity. The area of such lakes is usually greater than 50 hectares. There are 53 lakes of national importance where fishing permits must be issued (an area greater than 50 hectares). These lakes are distributed in 14 counties of the country. Most of these lakes are in Utena County (30 lakes) - in Ignalina (10 lakes), Moletai (10), Utena (5) and Zarasai (5 lakes) district.

Table 2. Classification of lakes according to fish breeds according to lake size (f) and average depth (h)

\begin{tabular}{|c|c|c|c|c|}
\hline Dominant fish breeds & f, ha & h, $\mathbf{m}$ & $\begin{array}{c}\text { Number } \\
\text { of lakes }\end{array}$ & $\begin{array}{c}\text { Number } \\
\text { of lakes, } \\
\%\end{array}$ \\
\hline Crucian: perches, crucians & $<5$ & $<4$ & 98 & 28 \\
\hline Pike: tench, roach, pike & $5-20$ & $4-10$ & 49 & 14 \\
\hline Weakfish: ablet, bream, ruff, pike & $20-100$ & $4-10$ & 149 & 43 \\
\hline Bream: ablet, bream, ruff & $20-100$ & $>10$ & 24 & 7 \\
\hline Osmeridae: smelts, ciscos & $>100$ & $>10$ & 27 & 8 \\
\hline Total: & & & 347 & 100 \\
\hline
\end{tabular}

Area and average depth of lakes are important for using the lakes in fishing, since they determine the prevailing fish species. Smelt, vendace (whitefish) - the most valuable lake fish prevail in 100 ha and deep lakes (average depth is more than $10 \mathrm{~m}$ ). There 27 such lakes in Utena County. Among bathymetrically explored lakes there are 150 lakes of 20-100 ha area and 4-10 m average depth, where are many bream, ablet, and pike. Small and shallow lakes are less valuable due to prevailing low-value fish species (perch, crucians and carps).

The underwater fishing permitted in 10 Lithuanian lakes. Eight of these lakes are in Utena County (Alausas, Antalieptes Pond, Asveja, Baltieji Lakajai, Druksiai, Galuonai, Sartai, Siesartis). So, Utena County really has a lot of lakes where there are valuable fish that can attract fishermen. 


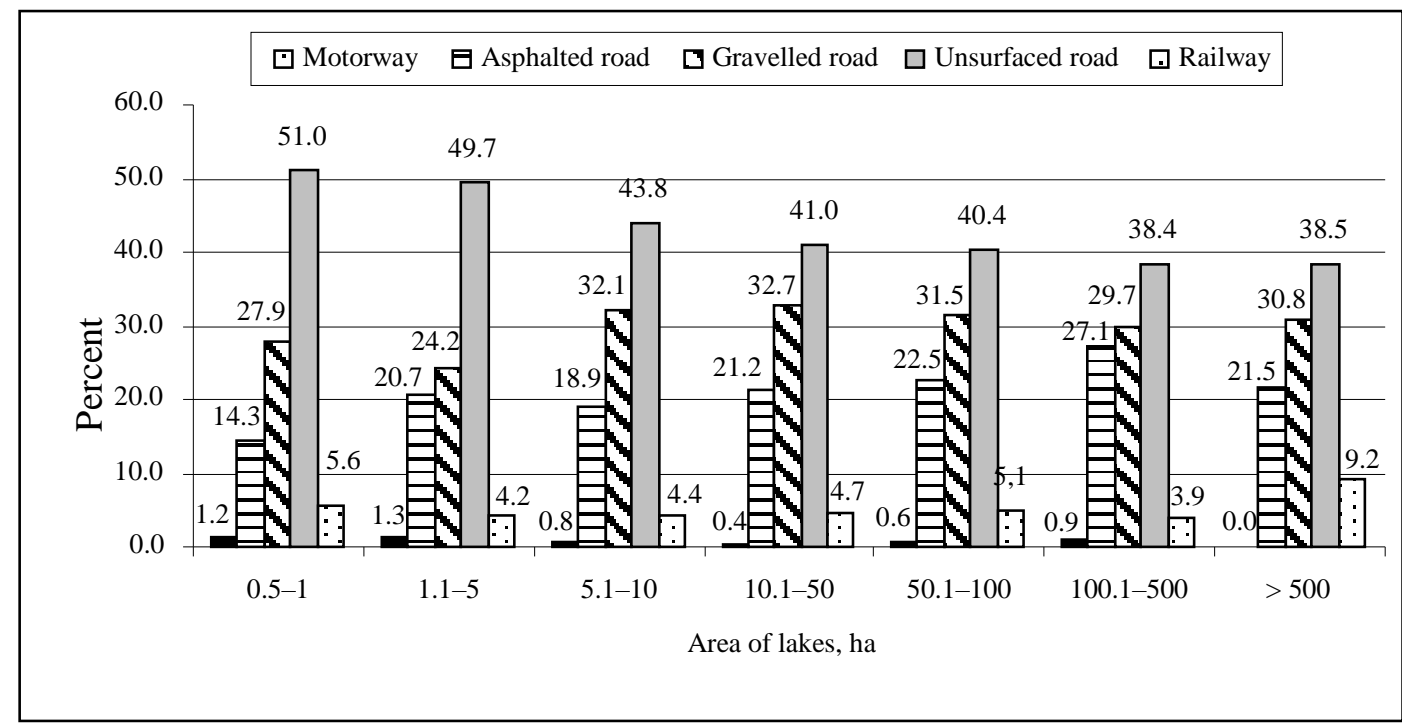

Figure 2. Number of lakes nearby which at a distance of $500 \mathbf{m}$ there are roads of certain types according to the various area classes

The lake shore landscapes are very important for the development of tourism. Tourism development near lakes which are not accessible for roads is quite limited. There are all types of roads nearby bigger than 0.5 ha Utena County lakes at a distance of $500 \mathrm{~m}$ - motorways, asphalted roads, gravelled roads, unsurfaced roads and railways (Figure 2). The research data shows that gravelled roads (30\% of all lakes can be reached by these roads) and unsurfaced roads (41\%) predominate. Such situation exists because in Lithuania (and Utena County) the majority of roads are of the above mentioned type.

There is a tendency that the bigger a lake is the greater variety of road types within a radius of $500 \mathrm{~m}$ it has. For instance, unsurfaced roads are nearby a half of total small $0.5-5$ ha lakes. With the increase of the area of a lake the number of lakes having gravelled and unsurfaced roads becomes bigger. For example, asphalted roads are nearby $22 \%$ of all bigger than 500 ha lakes and nearby $14 \%$ of smaller than 1 ha lakes. Railways are nearby $9 \%$ of all bigger than 500 ha lakes.

There are 80 lakes (>0.5 ha) nearby at a distance of $10 \mathrm{~m}$ from gravelled roads and 69 lakes near unsurfaced roads. However, at a distance of $500 \mathrm{~m}$ their number increases up to 631 and 933 respectively. Thus it can be concluded that the bigger distance from the lake, the more and more various types of roads exist.

Forests, grasslands, populated areas and swamps are nearby the lakes of all area classes at a distance of $500 \mathrm{~m}$. With the increase of a lake area the number of lakes on the shores of which there are swamps, areas covered by grasslands increase, the number of forests decreases (Figure 3). Nearby the smaller lakes the bigger percentage of the shore territory is covered with forests and other landscapes. The typical Utena district lake (>0.5 ha) in a $500 \mathrm{~m}$ radius from its shore will have the following landscape structure: $60 \%$ of grasslands, $36 \%$ of forests, $3 \%$ of populated areas, $0.1 \%$ of swamps and $1 \%$ of other landscapes. 


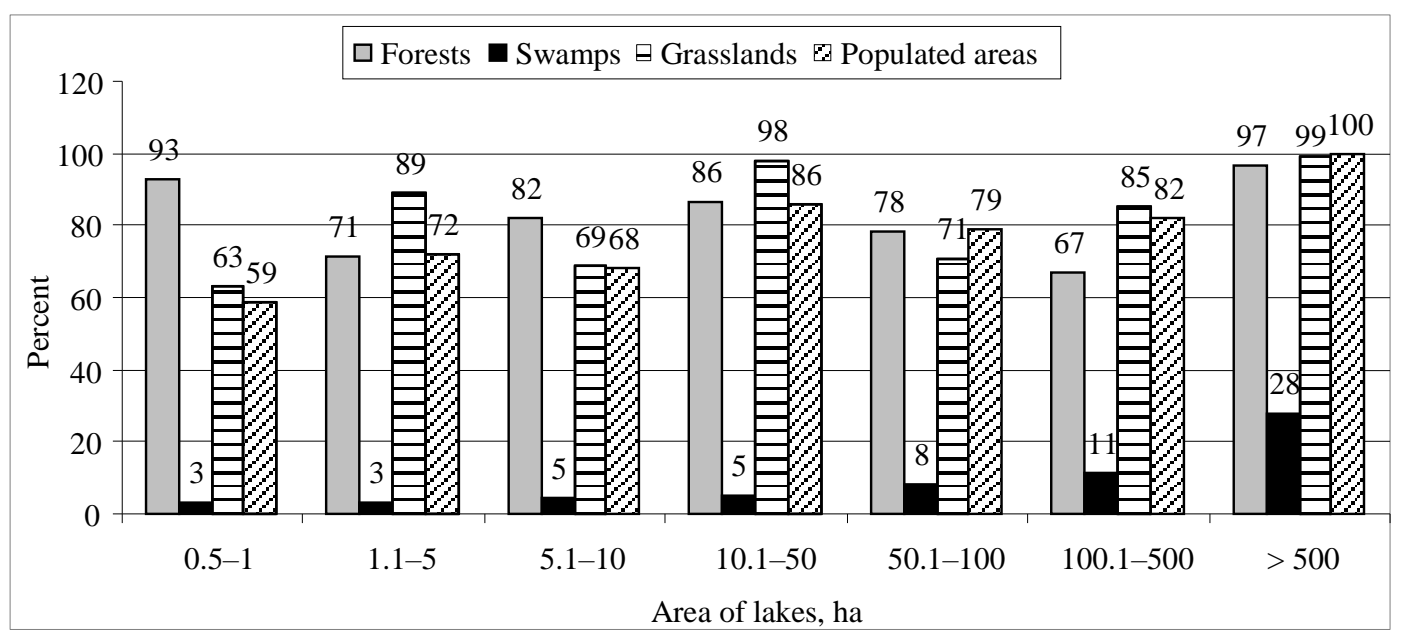

Figure 3. Number of lakes nearby which at a distance of $500 \mathbf{m}$ there is a landscape of some type $(\%)$ according to various area classes

Lakes near the forest are important for recreation. With the increasing area size of lakes, the areas on the shores of lakes covered by forests and grasslands also increase.

One more type of the anthropogenised landscape is populated areas. They are found near the exploratory lakes of all the area classes at a distance of $500 \mathrm{~m}$ (Figure 4). The most distinguishable lakes are those that have the smallest and the biggest areas. Near the lakes that are of 0.5-1 ha there are no towns at all and near half of all the lakes from this class (54\%) there are populated areas having fewer than 20 people. Meanwhile, near all bigger than 500 ha lakes there are populated areas of this type and towns are near $7 \%$ of them.

Populated areas are near all bigger than 500 ha lakes and the majority of lakes of other classes. The smallest number of lakes from the $0.5-1$ ha class are nearby the populated areas (59\%) (Fig. 3). This can be explained by the fact that small lakes are most often surrounded by the landscape, e.g. the forest. To compare, in $0.5-1$ ha class there are 80 lakes (16\%) surrounded only by the forest; in 1.1-5 ha class - 64 lakes (6\%); in 5.1-10 ha class -9 lakes (2\%); in 50.1-100 ha class -4 lakes $(0.6 \%)$.

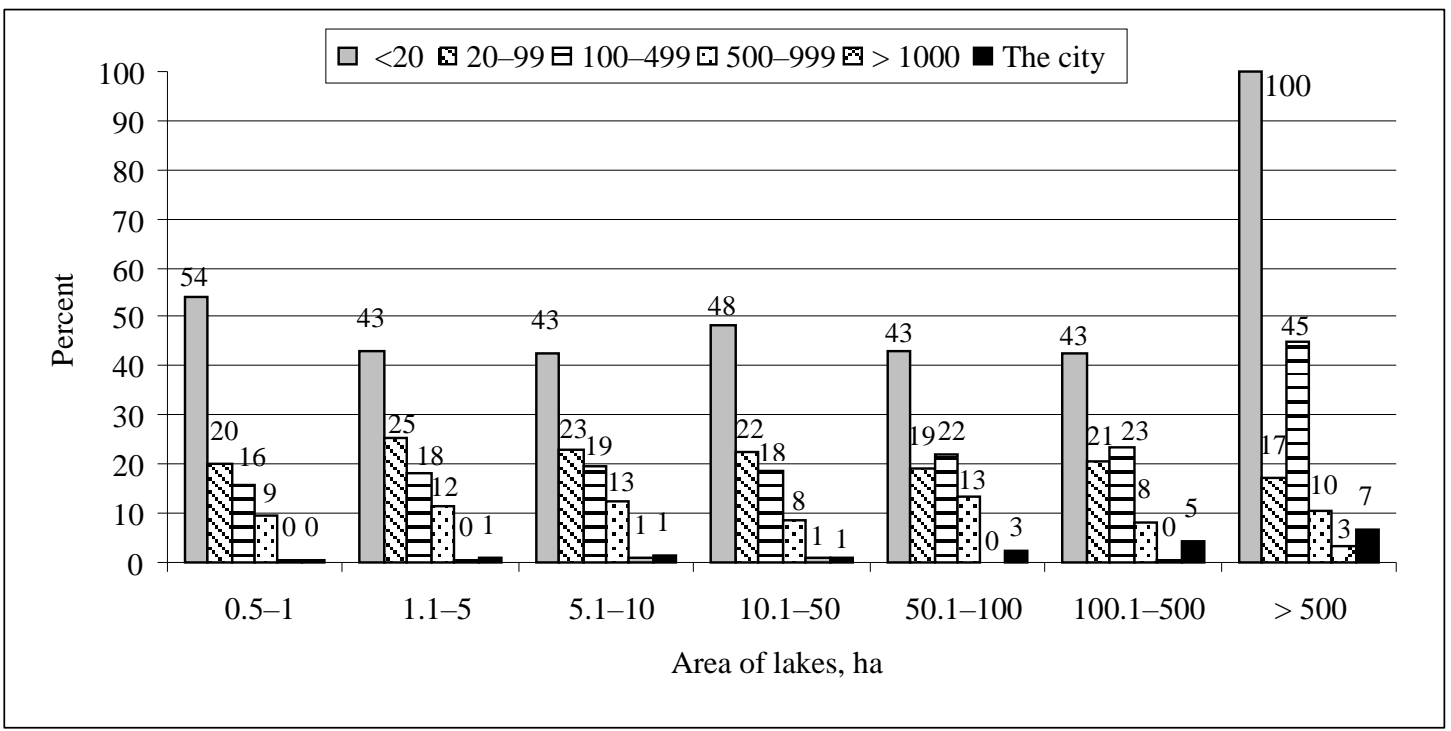

Figure 4. Number (\%) of lakes nearby which at a distance of $\mathbf{5 0 0} \mathbf{m}$ there are populated areas in the various area classes 
Though populated areas are found nearby all bigger than 500 ha lakes, they cover a very small percentage of the territory (just 2.02\%) (Daubariene et al., 2011 a). A smaller percentage of populated areas on the shores of big lakes could have been determined by the influence of a water body on the microclimate.

Utena County is a land of hills, thick forests and picturesque lakes. Tourism enterprises (rural tourism, camping, accommodation enterprises, boats rent etc.) are near 99 lakes. Tourism is being developed near $10 \%$ of the total Utena district lakes. There are several tourism service providers' concentrations around the lakes of the region. These service clusters are located on the lakes of Alausas (4 enterprises) and Rubikiai (7) in Anyksciai municipality. In Utena municipality these are the lakes of Alausas (15), Tauragnas (3), Klykiai (4), and Utena pond (3). In Moletai municipality - Baltieji Lakajai, Virinta (4) and Bebrusu (3) lake. In Zarasai municipality these are the lakes of Sartai (12), Luodzio (5) and Antalieptes pond (7). Service providers in Ignalina municipality are spread all over the districts among dense concentration of the lakes. Most of them are within the territory of the Aukstaitija National Park.

Exceptional water tourism and recreational infrastructure is created on the lakes Laukesa, Siekstis (Zaliasis), Lusiu, Baltieji Lakajai, Alausas, Zarasas, Grabuostas (Daubariene et al, 2011 a). The majority of tourism enterprises are concentrated near larger lakes.

There are 206 rural tourism enterprises in Utena County. 185 rural tourism enterprises (almost 90\%) are not further than 500 meters from the lakes. 60\% of the rural tourism is concentrated near the lakes in Anyksciai municipality. Most of the farmsteads in Anyksciai municipality are located near the river Sventoji. Almost $99 \%$ of rural tourism of Zarasai municipality is near lakes (Table 4).

Table 4. Rural tourism homesteads near lakes

(Information gathered by Utena County municipalities Tourism Information Centres websites)

\begin{tabular}{|l|c|c|c|c|c|}
\hline \multirow{2}{*}{ Municipality } & \multirow{2}{*}{$\begin{array}{c}\text { Rural } \\
\text { tourism } \\
\text { homesteads, } \\
\text { units }\end{array}$} & Units & $\%$ & Bedspace & $\begin{array}{c}\text { Average distance from } \\
\text { the lake to rural tourism } \\
\text { homesteads, in meters }\end{array}$ \\
\cline { 3 - 6 } & 28 & 17 & 61 & 493 & 59 \\
\hline Anyksciai & 54 & 50 & 93 & 651 & 103 \\
\hline Ignalina & 31 & 29 & 94 & 930 & 65 \\
\hline Moletai & 37 & 34 & 92 & 783 & 82 \\
\hline Utena & 56 & 55 & 98 & 895 & 74 \\
\hline Zarasai & $\mathbf{2 0 6}$ & $\mathbf{1 8 5}$ & $\mathbf{9 0}$ & $\mathbf{3 7 5 2}$ & $\mathbf{7 7}$ \\
\hline Total: & & & & & \\
\hline
\end{tabular}

Most rural tourism places are located on average 77 meters from the lakes shores. Rural tourism is located on average 103 meters from the lakes in Ignalina district. It should be noted that 19 rural tourism places of the region are in the Aukstaitija National Park, where the distance from the building to the water body is regulate by legislation. All rural tourism providers of Utena district provide boat rental and others water activities.

There are 7 camping sites in Utena district. (Zarasai -2 , Moletai -3 , Utena -1 , Ignalina -1 ). All camping sites are near the lakes. 


\section{CONCLUSIONS}

1. Utena County has $35 \%$ of all Lithuanian lakes larger than 0.5 ha, $66 \%$ of all Lithuanian lakes larger than 500 ha.

2. The research data shows that lake area, accessibility by roads and lake landscape structure are important factors for lake tourism development. In large lakes there are possibilities to organize boating with motorized or non-motorized boats, sailing, swimming, fishing, diving, etc.

3. Recreational activities on large lakes are more diverse and attractive than the ones small lakes. Large lakes of Utena County are better accessible by different types of roads.

4. The comparative landscape structure of a lake bigger than 0.5 ha in a $500 \mathrm{~m}$ shore zone currently can be described as follows: $60 \%$ is made of grasslands, $36 \%$ - of forests, $3 \%$ populated territories, $0.1 \%$ - swamps and $1 \%$ - other landscapes. Large lakes' landscape structure is more diverse and attractive.

5. The small Utena County lakes are more suitable for the development of eco-tourism and large lake (area $>50 \mathrm{ha}$ ) - for mass tourism (just $10 \%$ of Utena County lakes).

6. Utena County has 206 rural tourism enterprises. 185 rural tourism enterprises (almost 90\%) are not further than 500 meters from the lakes. In Utena district there are 7 camping sites. All camping sites are near the lakes. Tourism enterprises clusters are located at the lakes of Alausas, Rubikiai, Sartai and Antalieptes Pond.

\section{REFERENCES}

1. Daubarienè, J., Valiuškevičius, G., Asijavičiūtè, V. (2011 a). The influence of morphometric characteristics on the functional usage of Lithuanian lakes. Environmental engineering: Proceedings of 8th International Conference (pp. 543-548).

2. Daubarienè, J., Valiuškevičius, G., Asijavičiūtè, V. (2011 b). The structure of the landscape of Lithuanian lake shores of various sizes. Aplinkos apsaugos inžinerija: 14-osios Lietuvos jaunuju mokslininku ,Mokslas - Lietuvos ateitis“ straipsniu rinkinys (pp. 100-107).

3. Dèl aplinkosaugos sąlygu plaukioti vandens telkiniuose plaukiojimo priemonèmis ir vandens telkiniu, kuriuose plaukiojimas tam tikromis plaukiojimo priemonemis draudžiamas ar ribojamas, sąrašo patvirtinimo (2004, Nr. 58-2073). Prieiga internetu:

http://www3.lrs.lt/pls/inter3/dokpaiska.showdoc_1?p_id=367592\&p_query=\&p_tr2=[Žiūrèta $20141001]$.

4. Dèl LR ežeru klasifikatoriaus patvirtinimo. (2003). Lietuvos respublikos Aplinkos ministro įsakymas Nr. 130. Valstybès žinios, 34, 1442.

5. Goeldner, C. R., Ritchie, J. R., McIntosh, R. W. (2000). Tourism. Principles, Practises, Philosophies. John New York: Wiley \& Sons, Inc.

6. Hall, C. M., Härkönen T. (2006). Lake Tourism: An Integrated Approach to Lacustrine Tourism Systems. Canada.

7. Lerner, M., Haber, S. (2000). Performance factors of small tourism ventures: The interface of tourism, entrepreneurship and the environment. Journal of Business Venturing, 16, 77-100.

8. Ranade, P. S. (2008). Managing Lake Tourism: Challenges Ahead. Conference on Tourism in IndiaChallenges Ahead, 543-554 
9. Ryhanen, H. (2001). The touristic profile and potential of European lake destinations. Atlas 10th Anniversary International Conference, 4-6.

10. Rytu Lietuvos vandens turizmo plètros galimybiu studija. (2003). Vilnius.

11. Virbickas, T. Domarkas, A. (2006). Vandens telkinių tinkamumas mėgèjiškai žuvininkystei, rekreacinès žūklès plètra. Lietuvos vidaus vandenu žuvininkystès ir žuvivaisos plètra, 1, 19-21.

\title{
LAKES TOURISM DEVELOPMENT IN UTENA COUNTY
}

\author{
Daubarienė Jurgita \\ University of Applied sciences of Utena, Utena, Lithuania
}

\begin{abstract}
Research background. The biodiversity of lakes makes them important as natural resource for tourism. Lakes all over the world are used as a resource for ecotourism, natural tourism, leisure tourism and they attract millions of tourists. The use of lakes for sports, entertainment, swimming, fishing, etc. is of great importance to the public. There are 2833 lakes larger than 0.5 ha in Lithuania. Utena County has 35\% share of all Lithuanian lakes larger than 0.5 ha. So this is a very important region of lake tourism development in Lithuania.
\end{abstract}

Research aim. The object of the research is bigger than 0.5 ha lakes of Utena County, and the research aim is to analyse lake tourism development in Utena County.

Methods. Scientific literature, web sites, legislation on lake tourism and recreational activities on the lakes and in the lakeshore, ArcGis software programme were used as references for writing the article.

There are 1001 lakes, bigger than 0.5 ha, in Utena County. Since there are a great number of lakes, in order to distinguish their patterns, lakes were grouped into 7 area classes: $0.5-1$ ha; $1.1-5$ ha; $5.1-10$ ha; 10.1-50 ha; 50.1-100 ha; 100.1-500 ha; > 500 ha. Articles distinguish the most important criteria of lakes tourism development: lakes morphometric parameters, lakes accessibility of roads, landscape structure of lakes. The marphometric parameters, used in the present paper, were taken from the Catalogue of Lithuania SSR lakes (1964), while bathymetric parameters were taken from list with bathymetric data (1964). To determine the accessibility of lakes, ArcGis10 software was used. It was worked with GDB10LT database (updated in January, 2008). The data of lakes was taken from layer "Areas". This layer of lakes was recovered with layers of "Roads" and "Railways". Seeking to assess the accessibility of lakes by roads of various types, search for roads was implemented at the radius of 10, 50, 100, 200 and 500 metres around lakes. The paper sought to determine the landscape structure of Utena County lakes. The distribution of forests, swamps, grasslands, residential areas and other landscapes in lake shores was analysed. These landscapes were analysed in buffers, drawn at the radius of $500 \mathrm{~m}$ around lakes. Forests, swamps, residential areas and other landscapes were taken from GDB10LT layer "Locations". After drawing the buffers of $500 \mathrm{~m}$ radius around lakes, the area of forests, swamps, residential areas and other landscapes was calculated.

Results. The research data shows that the most common lakes in Utena County are small lakes, less than 50 hectares ( 881 lakes). There are 29 lakes larger than 500 ha in Lithuania. Utena County has $69 \%$ share of all Lithuanian lakes larger than 500 ha. It is very important for development of recreational activities because the bigger the lake - the greater the opportunity to deploy it. Utena County has 374 lakes (37\%) where you can use self-propelled boating means (area more than 10 hectares) and 60 lakes (6\%) (larger than 
200 hectares) where you can use more high-powered boats. The water motorcycles can be used just in the Alausas Lake. Based on the morphometric lake parametres - area and average depth, lakes, suitable for pikes (45\% of all the lakes explored), crucians (36\%) and breams, pike perches (18\%) predominate.

There are all types of roads near bigger than 0.5 ha Utena County lakes at a distance of $500 \mathrm{~m}-$ motorways, asphalted roads, gravelled roads, unsurfaced roads and railways. The research data shows that gravelled roads (30\% of all lakes can be reached by these roads) and unsurfaced roads (41\%) predominate. There is a tendency that the bigger a lake is the greater variety of road types within a radius of $500 \mathrm{~m}$ it has.

Forests, grasslands, populated areas and swamps are nearby the lakes of all area classes at a distance of $500 \mathrm{~m}$. With the increase of a lake area the number of lakes on the shores of which there are swamps, areas covered by grasslands increase, the number of forests decreases. Nearb the smaller lakes the bigger percentage of the shore territory is covered with forests and other landscapes. The typical Utena district lake (>0.5 ha) in a $500 \mathrm{~m}$ radius from its shore will have the following landscape structure: $60 \%$ of grasslands, $36 \%$ of forests, $3 \%$ of populated areas, $0.1 \%$ of swamps and $1 \%$ of other landscapes. The lakes near the forest are important for recreation. With the increasing size of lakes, the areas on the shores of lakes covered by forests and grasslands also increase.

Populated areas are near all bigger than 500 ha lakes and the majority of lakes of other classes. There are populated areas having fewer than 20 people near all the lakes bigger than 500 ha, towns are nearby $7 \%$ of such lakes. Almost $90 \%$ of Utena County tourism enterprises are not further than 500 meters from the lakes. Tourism enterprises clusters are located at the lakes of Alausas, Rubikiai, Sartai.

Conclusions. The research data shows that lake area, accessibility by roads and lake landscape structure are important factors for lake tourism development. In large lakes there are possibilities to organize boating with motorized or non-motorized boats, sailing, swimming, fishing, diving, etc. Recreational activities on large lakes are more diverse and attractive than the ones small lakes. Large lakes of Utena County are better accessible of different types of road. Large lakes landscape structure is more diverse and attractive. The small Utena County lakes are more suitable for the development of eco-tourism and large lake (area > $50 \mathrm{ha}$ ) - for mass tourism (just 10\% of Utena County lakes).

Keywords: lake tourism, lakes' morphometric parameters, lakes' accessibility by roads, landscape structure of lakes. 